\title{
DMA technology summit
}

Journal of Direct, Data and Digital Marketing Practice

(2013) 14, 359-360. doi:10.1057/dddmp.2013.28

\section{How the presidential race was won}

\author{
Preservers, \\ transformers, vanguard
}

\section{Channel 4 open and transparent with data}

\section{From product to channel to customer}

\section{Technology just there to achieve goals}

On 30 April 2013, the DMA held a Technology Summit - a slightly odd and (to your correspondent) not particularly enticing title for what proved to be a fascinating half-day, show-boating the technical guru who had masterminded Obama's re-election campaign last year.

Readers of this Journal may recall that, in July 2010, Mark Pack wrote a piece on the marketing lessons of Obama's first election campaign. ${ }^{1}$ Now we were to hear, from the horse's mouth, how the second race was won.

Before the keynote speaker, we were treated to three warm-up acts. The first was delivered by Phil Klaus, Professor of marketing strategy and customer experience (CX), Cranfield School of Management (among many other places). Professor Klaus asked what it was that drove customer behaviour and concluded that it was CX, which, he claimed, was the next competitive battleground of business. Eighty per cent of CEOs believed that their companies delivered a great CX only 8 per cent of their customers agreed.

Companies could be divided into three categories: preservers, who were trying to maintain their status quo; transformers, who were struggling towards new methods; and vanguard, who were in the lead. These produced net profits of 1.1 per cent, 4.1 per cent and 8.2 per cent, respectively. He regarded technology as the enabler of mass oneto-one marketing.

Klaus was followed by Steve Forde, Head of Viewer Relationship Management at Channel 4, who estimated that by 2020 two-thirds of TV viewing would be on connected devices. He described how Channel 4 (a not-for-profit company) collected customer data on whose use it was determinedly open and transparent - its primary value was in the opportunities it gave for segmentation.

Finally came Steve Plimsoll, Chief Technology Officer for Mindshare Worldwide and WPP Data Alliance. He recalled how business had gone through a phase of being product-centred, had progressed to being channel-centred and now required to change again to become customercentred. He decried the existence of customer silos, based on the products a customer bought, or the channels (s)he used.

Businesses must start with their users, not with data. Steve used data-rich slides and live examples to demonstrate the sort of insights that properly-constructed data (measured in terabytes) made possible, at every level of segmentation from an individual upwards.

After a short break for coffee and networking came our keynote speaker, Harper Reed, Chief Technology Officer for Obama for America 2012, described as a tech engineer, innovator and entrepreneur from Silicon Valley who had engineered the most sophisticated political 


\section{Building a community through micro-listening}

campaign of all time. Following what was by now a common theme of the conference, he insisted that technology was simply something that was there - available - to achieve whatever goals one sets oneself.

His constant drive in the election campaign was to build a great community and, at all stages in doing so, to practice failure. Failure, he insisted, would - despite rigorous testing that must be undertaken always occur: the important thing was to practice failure and recovery from it, such that it was invisible to the user.

The essence of building a community was what he described as micro-listening - every piece of information gained from email lists, from Facebook friends, from door knocking or from Twitter was fed back to the system to help in creating profiles of the consumer and to assist in the construction of the next move. (Some of the profiling techniques used, he speculated, would probably be banned on this side of the Atlantic, particularly in Germany.) He decried the use of the term big data, as though it were something new and different: data was just data, and the technology would handle it, however big.

The technical requirement of the campaign was to integrate all possible channels: first, for the construction of a community, secondly, for communication with that community, and thirdly, for intracommunity communication and through that communication with the wider electorate. Fundraising was a vital part of the campaign and the principal channel for this was email. SMS text messaging was also widely used and mobile apps were written.

A great deal depended on the team - technical and other - used to implement this campaign. Harper's first message here was prune your team, fire people who don't fit, however difficult it may be. When hiring at all levels, hire people smarter than yourself (a good recipe for a quiet life). A-level people will, if left to their own devices, hire A-level staff, but Bs will hire Cs and so on. Always look to hire people not just smarter, but different from yourself: diversity is highly important. Having done this, trust the people you have hired; celebrate success; give generous credit; and empower your users. And a simple ABC reminder - Always Be Closing: focus full-time on your objectives.

These presentations were followed by a panel of all four speakers, taking comments and questions from the floor. There was no lack of these, indicating that the event had been well appreciated by its audience. Proceedings were followed by lunch, and an opportunity to exchange impressions.

\section{Reference}

1. Pack, M. (2010) 'Obama: The marketing lessons', Journal of Direct, Data and Digital Marketing Practice 12(9 August): 2-9 doi: 10.1057/dddmp.2010.17. 